\title{
Evaluation of Academic Satisfaction of Graduates From the Ji-Paraná Campus of the Federal University of Rondônia
}

\author{
Aline Cristina Helfenstein ${ }^{1}$, Douglas Fernando Batista Neis ${ }^{1}$, Elielza Camargo Souza ${ }^{1}$, Fernando Hungaro Lemes \\ Gonçalves $^{2}$, Ronaldo Helfenstein ${ }^{3} \&$ Rosália Maria Passos da Silva ${ }^{1}$ \\ ${ }^{1}$ Public Administration (PROFIAP), Rondônia Federal University, Brazil \\ ${ }^{2}$ Administration (PPGMAD), Rondônia Federal University, Rondônia, Brazil \\ ${ }^{3}$ Administration and Accounting Department, Ouro Preto do Oeste College, Rondônia, Brazil \\ Correspondence: Douglas Fernando Batista Neis, Professional Master's Program in Public Administration \\ (PROFIAP), Rondônia Federal University, Rondônia, Brazil.
}

Received: May 1, 2020

doi:10.5430/ijba.v11n4p52
Accepted: June 17, 2020

Online Published: July 2, 2020

URL: https://doi.org/10.5430/ijba.v11n4p52

\begin{abstract}
This paper aimed to know the degree of academic satisfaction of the students of the Federal University of Rondônia, Campus of Ji-Paraná, with the institution, the course and the opportunity of development. Such a finding is of paramount importance to assist managers in making decisions, as it reveals in which areas they are serving in a more precarious way, as well as which ones have been observed as quality by students, which can increase or decrease the rate of participation of the students, for example, or, to produce more or less qualified professionals, according to the quality applied in the course. The development of the research had an exploratory character, of a quantitative nature, with a strategy of data collection through a questionnaire, based on the Scale of Satisfaction and Academic Experience (SSAE), and to measure the intensity of satisfaction, a five points Likert-type scale was used. As a unit of analysis, the Ji-Paraná Campus of the Federal University of Rondônia was defined. The research subjects were 65 students graduating from Environmental Engineering, Statistics, Physics, Mathematics and Pedagogy courses. The sample consisted of $66,2 \%$ women and $38,2 \%$ men and their average age was 27 years. As a result, it was found that students are satisfied in the three dimensions surveyed, with the greatest satisfaction recorded being with the course that obtained 3,86 points, followed by satisfaction with the institution that reached 3,47 points and satisfaction with the development opportunity with 3,45 points. Knowing satisfaction with the quality of services provided to students of the higher education can contribute to increase the demand for students at Federal Institution for Superior Education, as well as increase the permanence rate, and also the quality of the services delivered to society regarding to the formation of professionals.
\end{abstract}

Keywords: higher education, academic satisfaction, SSAE scale

\section{Introduction}

The main objectives of Public Universities are to offer quality education, conduct scientific research and develop extension activities. For these activities to be possible, the educational institution depends on the support of a community of people who gravitate towards it. An important part of this community is represented by students, whose satisfaction seems to be relevant (KOTLER, 1994) to maintain their support, both in internal activities and in attracting new students.

According to Moreira (2003), educational institutions that want to improve the level of education, making it more effective, should use a well-designed project, taking into account the basic elements of the teaching-learning process.

Durham (2009) says that the National Higher Education Assessment System (SINAES) used by the Ministry of Education (MEC) to measure the quality of higher education is insufficient to improve the quality of education, proposing that research must be carried out with graduates to find out if in fact the course offered them job opportunities.

Federal public universities are recognized for being the best institutions, those that deliver the best professionals to society. This type of Higher Education Institution does not aim at financial profit, but at social profit. They have better trained teachers and develop scientific research relevant to society. However, because they are not so 
concerned with "attracting new customers", as private universities, sometimes they are not so concerned with analyzing the satisfaction of their target audience, which are students.

For Schleich, Polydoro and Santos (2006), Brazil has been constantly growing in terms of the number of vacancies and, in parallel, greater efforts are needed in the development of structure, quality and teaching policies. Salomão, Abacar and Aliante (2018) say that knowing the level of academic satisfaction and the factors that influence it is necessary to plan and apply quality improvement strategies in higher education. Consequently, students who receive a higher level of learning will be better prepared professionals.

The present study is a marketing research approach, which, as defined by Malhotra (2012), consists of the identification, collection, analysis, dissemination and use of information in an organized manner that supports the manager in decision making and implementing improvements. In this specific case, the work intends to present results regarding the perception of satisfaction of the Federal University students in Ji-Paraná, providing information on which aspects or attributes the University is deficient about.

In this sense, corroborating the idea of the authors mentioned, it is understood that it is important to check the level of satisfaction of students who are at the university, striving for a current and future improvement in the Federal University standards, promoting a greater social profit affecting even the academic evasion process that today is widely perceived at the Ji-Paraná Campus.

Despite the academic satisfaction have been object of several studies, like Mainardes and Domingues (2010), Fadel et al. (2018), Santos et al. (2006), Salomão, Abacar and Aliante (2018), Dias Horiguela and Marchelli (2006), Ramos (2015) and Barboza et al. (2014), there weren't find studies related to the Federal University of Rondônia, and, for that, the importance of doing so by this paper, attending to a necessity of knowing the satisfaction levels of the students of this institution.

Thus, the general objective of this work is to know the degree of satisfaction of academics at the Federal University of Rondônia, Campus of Ji-Paraná, with the institution, the course and the opportunity for development. The specific objectives are: to identify the attributes to be addressed in the research (1); conduct data collection with students (2); analyze and determine the degree of academic satisfaction with the institution, the course and the opportunity for development (3);

The central problem of this research is: what is the degree of satisfaction of the academics at the Federal University of Rondônia, Campus of Ji-Paraná, regarding the institution, the course and the opportunity for development?

The next chapter will present a theoretical contribution that will serve as a reference for this study.

\section{Theoretical Reference}

Higher Education Institutions in Brazil have grown a lot recently. With this growth, the offer of vacancies has also been increasing. Public universities are known as a benchmark in quality and have their own teacher development policies. This results in more qualified institutions.

As a result of this evolution in higher education, the concern with student satisfaction started to gain proportion and this torn to be the subject of several studies such as Mainardes and Domingues (2010), Fadel et al. (2018), Santos et al. (2006), Salomão, Abacar and Aliante (2018), Dias, Horiguela and Marchelli (2006), Ramos (2015) and Barboza et al. (2014).

Mainardes and Domingues (2010) studied the satisfaction of business students at higher education institutions in Joinville, Santa Catarina state. These authors did a survey of attributes through bibliographic studies and then measured the students' satisfaction with these attributes. They found that the students were satisfied and that the institution's image was the main factor of satisfaction.

Fadel et al. (2018) analyzed the satisfaction of graduates in the area of Health Biological Sciences at a Brazilian public university. The data collection was carried out through a questionnaire with 35 indicators and 3 dimensions, where the dimension "satisfaction with the course" was the one that received the best evaluation, while "satisfaction with the institution", the worst. They concluded that academics are satisfied with the institution, but that strategies for improvement must be implemented.

Santos et al. (2006) evaluated the integration and academic satisfaction of 203 students in the psychology and dentistry courses of a private higher education institution. They used questionnaires on Academic Experience and an Academic Satisfaction Scale. The results found revealed that the students are satisfied and integrated. 
Salomão, Abacar and Aliante (2018) analyzed the academic satisfaction of undergraduate students in basic education at the Pedagogica University of Mozambique and their relationship with socio-demographic issues. They carried out data survey, through questionnaires with sociodemographic guidelines and satisfaction scale with the academic experience. These authors found that the worst dimension was "satisfaction with the course".

Dias, Horiguela and Marchelli (2006) analyzed the systems used to measure the quality of higher education. For this, they applied questionnaires to teachers, administrative officers and students, in order to evaluate the didactic and administrative structure, attendance to the expansion and the means of evaluation and teaching, research and extension.

Ramos et al. (2015) verified satisfaction with the academic experience and the relationship with the sociodemographic variables of 170 nursing students from a public university in southern Brazil. They used the Satisfaction Scale with Academic Experience, by which they found that students are neutral with regard to satisfaction, with "Satisfaction with the course" being the variable that obtained the best averages.

Barboza et al. (2014) analyzed the precepts that guide the satisfaction, dedication and performance of 176 students from two federal universities in northeastern Brazil. They applied a structured questionnaire and through statistical analysis found that academic performance is defined by personal commitment to studies and that academic satisfaction is a determining factor in the commitment of students.

For Vaduvaet al. (2011), educational activities are different from other activities, both the involvement of teachers and students, as well as educational assistance in general, and these aspects are guided by factors that have an impact on the quality of services provided.

Professional performance and what the student will represent in society depends, in part, on the quality provided in the student's education (VADUVA et al., 2011). In this sense, the quality of teaching impacts on the professional formation of academics.

Academic satisfaction was considered a determining aspect in the students' efforts in the studies explored by Barboza et al. (2014). This seems to corroborate the importance of raising the level of academic satisfaction, contributing to make students more interested in their education. Barboza et al. (2014) also found that student satisfaction is linked to factors such as physical structure, development of activities, reputation of the course and profession.

Checking the weaknesses, threats, difficulties and opportunities for advancement is essential to remain in the current market, which is highly demanding, thus allowing a greater degree of competitiveness vis-à-vis competitors (FLORIANO, SILVA AND DORNELES, 2017). Federal Higher Education Institutions (FHEI), although free, have lost space to private distance learning universities that offer affordable courses, but do not deliver the same quality as an FHEI.

What is becoming more noticeable every day is the availability of unoccupied places at FHEI while several students are paying tuition at private universities, the vast majority of distance learning.

According to Kotler and Keller (2012), educational institutions, as well as other non-profit entities, use marketing to promote improvements in their image and thus compete for audiences and resources. Reflecting this theory presented, it is observed that in recent times the Federal University of Rondônia has been much more concerned with publicizing its selection processes and activities, through more attractive media such as the Facebook and the institutional website. New layouts were developed, with the probable intention of drawing the attention of the public, as well as of potential suppliers or fund-raisers.

The next chapter is intended to present the methods, tools and how this research became operational.

\section{Methodology}

The present work has a post-positivist socio-philosophical aspect, of a quantitative character with an investigation strategy through cross-sectional data collection, with the application of a questionnaire-type data collection instrument with closed attributes (CRESWELL, 2010). The research takes an approach in order to identify, collect, analyze and disseminate information in order to guide the Federal University managers in their choices and decision making (MALHOTRA, 2012).

The sample was selected by convenience, considering that the students who are completing their courses have a greater capacity to express their opinions on the aspects that are under discussion in the present research. Beginner students or ones that haven't accomplished the major part of the course schedule possibly couldn't have an opinion about the course and the development opportunity. 
In this way, the departments of Environmental Engineering, Physics, Statistics, Mathematics and Pedagogy from the Federal University of Rondônia, campus of Ji-Paraná, were asked for reports generated by the Integrated System for the Management of Academic Activities (SIGAA) of students with "graduating" status and report of students enrolled in the subjects of "Course Completion Paperwork", as these have the characteristics of students who are close to the completion of the course, as well as the list of students' contacts.

The reports issued by the SIGAA system were confronted, thus eliminating duplicate names resulting in 141 students able to answer this research, as shown in Table 1. The data collection instrument was sent via email on November 8 , 2019, and the responses were collected until December 3, 2019. 65 students responded to the questionnaire within the established period.

Table 1. Elaborated by the authors

\begin{tabular}{lll}
\hline Course & Students able to respond & Respondent Students \\
\hline Environmental Engineering & 24 & 13 \\
\hline Statistics & 12 & 6 \\
\hline Physics & 47 & 22 \\
\hline Mathematics & 14 & 6 \\
\hline Pedagogy & 44 & 18 \\
\hline Total & $\mathbf{1 4 1}$ & $\mathbf{6 5}$ \\
\hline
\end{tabular}

As a data collection instrument, a structured questionnaire adapted from the SSAE Matrix - Satisfaction Scale with Academic Experience, was used and developed and tested by Schleich, Polydoro and Santos (2006). This matrix was used in several studies such as Salomão, Abacar and Aliante (2018), Santos et al. (2013), Santos and Romeiro (2017) and Ramos et al. (2015), thus presenting satisfactory validity.

As a response format for the data collection instrument, a Likert-type scale with five points was used, where for each of the thirty-five statements, the interviewees demonstrate their degree of agreement with each stimulus represented (MALHOTRA, 2012).

The adaptations made in the matrix are due to the fact that they better represent the reality of the Campus, facilitating the interpretation of the respondents and / or because they do not have direct influence with the object of the research and were shown inTable below:

Table 2. Elaborated by the authors

\section{Questionnaire proposed by Schleich, Polydoro and Authors adaptation Santos (2006)}

Dear student

The purpose of this instrument is to assess the degree of satisfaction you have assigned to different aspects of your academic experience.

Considering the confidentiality of your answers, we ask that you complete the instrument based on the analysis of what has been most common in your experience in higher education, in the institution and course you currently attend.

For each aspect you must indicate your degree of satisfaction, following the scale of 1 to 5 , with the extreme levels:
Dear student

I work at the Federal University Campus in Ji-Paraná, and I'm student of the Professional Master's Program in Public Administration (PROFIAP), at the Federal University of Rondônia, and under the guidance of Prof. Dr. Rosália Maria Passos da Silva, I am developing a research aimed at determining the perception of the degree of satisfaction of the graduating students of the Ji-Paraná's Campus, regarding the institution, the course and the development opportunity.

In this sense, the objective of this instrument is to assess the degree of satisfaction attributed by you to different aspects of your academic experience. 
1. Not at all satisfied and, 5. Totally Satisfied

There are no right or wrong answers. Indicate what you really feel.

Please do not leave items blank.

To inform your satisfaction with each aspect discussed below, take as a basis most of the situations experienced in your current academic experience.
Your answers are confidential and therefore, I ask you to complete the questionnaire based on the analysis of your experience in the course you currently attend.

For each aspect you must indicate your degree of satisfaction, following the scale of 1 to 5 , with 1 representing that you are not satisfied and 5 that you are completely satisfied.

There are no right or wrong answers. Indicate what you really feel.

Please do not leave items blank.

DATE........................

Name:

Age: ......... Gender: male ( ) female ( )

Course:

Shift:

Course moment: ( ) semester or ( ) series

Course: ( )

Institution:.

(1) Environmental Engineering

Do you intend to continue the current course?

(2) Statistics

Yes ( ) No ( )

Performs paid activity? Yes ( ) No ( )

(3) Physics

(4) Mathematics

(5) Pedagogy

Type of Activity:

Age:

This activity:

( ) occurs in alternate periods or without a fixed schedule

Gender: ( ) (1) Female (2) Male

( ) occupies only one period of the day

( ) is full time

Average number of weekly hours of work .....

\begin{tabular}{|c|c|c|c|}
\hline & & Satisfaction with the Institution & \\
\hline & & Construct & Evaluation \\
\hline 1. Relationship with teachers & $\begin{array}{llll}(1) & (2) & (3) & (4) \\
(5) & & & \end{array}$ & $\begin{array}{l}\text { 1. Audiovisual resources and } \\
\text { equipment available at the } \\
\text { institution }\end{array}$ & (1) (2) (3) (4) (5) \\
\hline $\begin{array}{l}\text { 2. Diversity of extracurricular activities } \\
\text { offered by the institution }\end{array}$ & $\begin{array}{llll}(1) & (2) & (3) & (4) \\
(5) & & \end{array}$ & $\begin{array}{l}\text { 2. Service and clarity of } \\
\text { information offered by the } \\
\text { employees of the secretariat and } \\
\text { the course department }\end{array}$ & $(1)(2)(3)(4)(5)$ \\
\hline 3. Course curriculum & $\begin{array}{llll}(1) & (2) & (3) & (4) \\
(5) & & & \end{array}$ & $\begin{array}{l}\text { 3. Equipment and software } \\
\text { offered by the laboratories }\end{array}$ & $(1)(2)(3)(4)(5)$ \\
\hline $\begin{array}{l}\text { 4. Audiovisual resources and equipment } \\
\text { available at the institution }\end{array}$ & $\begin{array}{llll}(1) & (2) & (3) & (4) \\
(5) & & \end{array}$ & $\begin{array}{l}\text { 4. Service and clarity of } \\
\text { information offered by library } \\
\text { staff }\end{array}$ & $(1)(2)(3)(4)(5)$ \\
\hline 5. Relationship with classmates & $\begin{array}{llll}(1) & (2) & (3) & (4) \\
(5) & & & \end{array}$ & $\begin{array}{l}\text { 5. Collection available in the } \\
\text { library (digital included) }\end{array}$ & $(1)(2)(3)(4)(5)$ \\
\hline 6. Social events offered by the institution & $\begin{array}{llll}(1) & (2) & (3) & (4) \\
(5) & & & \end{array}$ & $\begin{array}{l}\text { 6. Security offered by the } \\
\text { institution (ordinance, security }\end{array}$ & $(1)(2)(3)(4)(5)$ \\
\hline
\end{tabular}


guards)

7. Service and clarity of the information offered by the employees of the secretariat

8. Adequacy between personal involvement in the course and the academic performance obtained

9. Personal involvement in the course activities

10. Student support programs or services offered by the institution

11. Conditions offered for my professional development (knowledge and skills for acting)

12. Teachers' interest in attending students during classes
(1) (2) (3) (4) 7. Physical infrastructure of (5)
(1) (2) (3) (4) (5)

(1) (2) (3) (4) (5)
(1) (2) (3) (4) 8. Physical infrastructure of the (5) institution

(1) (2) (3) (4) (5)

$\begin{array}{llllll}\text { 9. Institution cleanliness } & \text { (1) (2) (3) (4) (5) } \\ \text { (1) (2) (3) (4) } & \begin{array}{l}10 . \text { Services offered by the } \\ \text { library }\end{array}\end{array}$

(1) (2) (3) (4) 11. Comfort of the institution's

(5) facilities

(1) (2) (3) (4) (5)

12. Location of the different sectors that make up the (1) (2) (3) (4) (5) institution

\section{Course Satisfaction}

\begin{tabular}{|c|c|c|c|}
\hline $\begin{array}{l}\text { 13. Knowledge of teachers about the } \\
\text { content of the subjects they teach }\end{array}$ & $\begin{array}{llll}(1) & (2) & (3) & (4) \\
(5) & & & \end{array}$ & 13. Relationship with teachers & $(1)(2)(3)(4)(5)$ \\
\hline $\begin{array}{l}\text { 14. Recognition by teachers of my } \\
\text { involvement with my training }\end{array}$ & $\begin{array}{llll}(1) & (2) & (3) & (4) \\
(5) & & & \end{array}$ & $\begin{array}{lll}14 . & \text { Relationship } & \text { with } \\
\text { classmates }\end{array}$ & $(1)(2)(3)(4)(5)$ \\
\hline $\begin{array}{l}\text { 15. Equipment and software offered by } \\
\text { the computer lab }\end{array}$ & $\begin{array}{llll}(1) & (2) & (3) & (4) \\
(5) & & \end{array}$ & $\begin{array}{l}\text { 15. Adequacy between personal } \\
\text { involvement in the course and } \\
\text { the academic performance } \\
\text { obtained }\end{array}$ & $(1)(2)(3)(4)(5)$ \\
\hline $\begin{array}{l}\text { 16. Service and clarity of information } \\
\text { offered by library staff }\end{array}$ & $\begin{array}{llll}(1) & (2) & (3) & (4) \\
(5) & & \end{array}$ & $\begin{array}{l}\text { 16. Teachers' interest in } \\
\text { attending students during } \\
\text { classes }\end{array}$ & (1) ( \\
\hline
\end{tabular}

17. Conditions for entering the professional training area (insertion strategies and contact with the world of work)

(1) (2) (3) (4)

(1) (2) (3) (4)

(1) (2) (3) (4)

(5)
17. Knowledge of teachers about the content of the (1) (2) (3) (4) (5) subjects they teach

\begin{tabular}{|c|c|c|c|}
\hline 18. Collection available in the library & $\begin{array}{llll}(1) & (2) & (3) & (4) \\
(5) & & & \end{array}$ & $\begin{array}{l}\text { 18. Recognition by teachers of } \\
\text { my involvement with my } \\
\text { training }\end{array}$ & (1) (2) (3) (4) (5) \\
\hline $\begin{array}{l}\text { 19. Security offered by the institution } \\
\text { (ordinance, security guards) }\end{array}$ & $\begin{array}{llll}(1) & (2) & (3) & (4) \\
(5) & & & \end{array}$ & $\begin{array}{l}\text { 19. Institution's commitment to } \\
\text { formation quality }\end{array}$ & $(1)(2)(3)(4)(5)$ \\
\hline 20. Physical infrastructure of classrooms & $\begin{array}{llll}(1) & (2) & (3) & (4) \\
(5) & & & \end{array}$ & $\begin{array}{l}\text { 20. Evaluation proposed by } \\
\text { teachers }\end{array}$ & $(1)(2)(3)(4)(5)$ \\
\hline $\begin{array}{l}\text { 21. Institution's commitment to formation } \\
\text { quality }\end{array}$ & $\begin{array}{llll}(1) & (2) & (3) & (4) \\
(5) & & & \end{array}$ & $\begin{array}{l}\text { 21. Class strategy used by } \\
\text { teachers }\end{array}$ & (1) (2) (3) (4) (5) \\
\hline 22. Institution's physical infrastructure & $\begin{array}{llll}(1) & (2) & (3) & (4) \\
(5) & & & \end{array}$ & 22. Relevance of course content & $(1)(2)(3)(4)(5)$ \\
\hline $\begin{array}{l}\text { 23. Financial support program offered by } \\
\text { the institution }\end{array}$ & 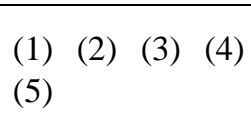 & $\begin{array}{l}\text { 23. Availability of teachers to } \\
\text { serve students outside the } \\
\text { classroom }\end{array}$ & $(1)(2)(3)(4)(5)$ \\
\hline
\end{tabular}


24. Opportunity for personal (1) (2) (3) (4) 24. Adequacy of course content

development offered by the institution for student formation

(1) (2) (3) (4) (5)

25. Adequacy between the tasks

25. Evaluation proposed by teachers

(1) (2) (3) (4) required in the course and the time set by the teachers to

(1) (2) (3) (4) (5) perform

\section{Satisfaction with the Development Opportunity}

26. Adequacy between my financial investment to pay for studies and the formation received
(1) (2) (3) (4)
(5)

(2) (3) (4)

26. Diversity of extracurricular activities offered by the institution

(1) (2) (3) (4)

27. Cleanliness of the institution

(1) (2) (3) (4)

28. Class strategy used by teachers

(1) (2) (3) (4)

29. Services offered by the library

30. Comfort of the institution's facilities

(1) (2) (3) (4)

27. Course Curriculum

(1) (2) (3) (4) (5)

28. Social events offered by the institution

(1) (2) (3) (4) (5)

29. Personal involvement in the course activities

(1) (2) (3) (4) (5) 30. Student support programs or services offered by the institution

(1) (2) (3) (4) (5)
31. Conditions offered for my

31. Relevance of the content of the subjects

development (knowledge and skills for acting)

\section{Conditions for entering the}

32. Location of the different sectors that

(1) (2) (3) (4) professional formation area

make up the Institution
(1) (2) (3) (4) (5) with the world of work)

\section{Availability of teachers to serve} students outside the classroom

34. Adequacy of course content for formation

35. Matching the tasks required in the course and the time

established by teachers to carry out
(1) (2) (3) (4) 33. Financial support program

(1) (2) (3) (4) offered by the institution 34. Opportunity for personal institution

(1) (2) (3) (4) (5) development offered by the (1) (2) (3) (4) (5)

(1) (2) (3) (4) 35. Adequacy between my

(5) financial investment to pay
studies and training received

Other comments about your satisfaction with the current academic experience (use the back if necessary):

Other comments about your satisfaction with the current academic experience:

Summary of adaptations made

The adaptations realized in the applied matrix are: suppression of part of the characterization of the respondents (name, date, shift, time of the course, institution, intends to continue the current course, exercise paid activity, type of activity and period of activity, average number of weekly hours of work); The item "7 Service and clarity of information offered by the employees of the secretariat" was changed to "Service and clarity of the information offered by the employees of the secretariat (SERCA) and the Department"; The item "18 Collection available in the library" has been changed to "Collection available in the library (including digital)"; Reordering the constructs according to the area to be evaluated, whether institution, course or development opportunity, grouping the constructs of each area. 
The hypothesis to be tested is that the students of the Federal University of Rondônia, Campus of Ji-Paraná are satisfied with the institution, with the course and with the opportunity of development. For that, were used the variables of the construct, in the items 1 to 35 .

The questionnaires were applied to the participants of the research, using the platform Google Forms, were it was transcribed the right column of the Table 2. The participants were notified via e-mail about the research and the opportunity to participate, while they inserted the data on the forms, the data was gathered together in a spreadsheet.

The data obtained through the application of the questionnaires were tabulated using the Software SPSS v. 24, by the importation of spreadsheet generated by the Google Forms platform. For data analysis, descriptive statistics, average ranking (AR) and average of ARs were used.

The main information used was the AR proposed by Fonseca and Santos (2015), where the weighted average for each attribute is calculated, based on the frequency of responses. The closer the AR is to 5, the greater the perception of satisfaction.

The AR calculation was obtained using the following formula:

$$
A R=\frac{\left(\sum f_{i} \times v_{i}\right)}{n}
$$

Then:

$\mathrm{AR}=$ Average Ranking;

f_i = Observed frequency (per answer and item);

$\mathrm{v} \_\mathrm{i}=$ Value of each answer (from 1 to 5);

$\mathrm{n}=$ Total number of informants (Sample);

In addition to the simple tabulations, cross-tabulated data were tabulated regarding the satisfaction with the course dimension, to delimit the students' satisfaction with each evaluated course, thus providing a specific report in the dimension, which allows each coordination to analyze the perception of its students regarding the course linked.

The results were analyzed by dimension studied, considering the following intervals for measuring academic satisfaction: from 1 to 2 - Very Dissatisfied, from 2 to 3 - Dissatisfied, from 3 to 4 - Satisfied and from 4 to 5- Very Satisfied;

The data collection instrument was subjected to a functionality test with 6 students. It was found that the questions were well structured and no changes were necessary. To analyze the reliability of the data collection instrument, Cronbach's alpha was used, which according to Malhotra (2012) varies from 0 to 1 , with an alpha of 0.6 or less indicating unsatisfactory reliability. Thus, the higher the results, the better the data collection instrument. In this test the alpha was calculated using the SPSS software, v24, resulting in 0.965 , confirming the reliability and validity of the construct.

\section{Discussion and Data Analysis}

Of the 141 questionnaires sent, 65 were returned, as shown in Table 1 (contained in the methodology chapter). In this sense, the error and the confidence level of the respondent sample in relation to the general population initially chosen as the sample were calculated. Thus, according to the formula proposed by Silva (1997) (below), the level of confidence that the sample used represents reality is $93 \%$ with a margin of error of $9 \%$.

$$
n=\frac{Z^{2} p q N}{(N-1) E^{2}+Z^{2} p q}
$$

Then:

$$
\begin{gathered}
n=\text { sample } \\
Z=\text { thevalueof theinverseofthestandardizednormaldistributionthatdependsonthe } \\
\text { levelofsignificance } \propto ; \\
p=\text { positivevariability; } \\
q=\text { negativevariability; } \\
N=\text { populationsize; }
\end{gathered}
$$




$$
E=\text { accuracy } \vee \text { error }
$$

The construct's validity was verified again, in the same way as the pre-test, after tabulation of all questionnaires, while the resulting Cronbach's alpha was 0.962 , which confirms the validity and reliability of the data collection instrument used.

In the next sub-chapters, the sample will be characterized, as well as data analysis will be carried out according to the proposed dimensions, which are: satisfaction with the institution, with the course and with the opportunity for development.

In a somewhat similar way to that of Salomão, Abacar and Aliante (2018), for data analysis, 1 will be considered 1 as totally dissatisfied, 2 as slightly dissatisfied, 3 as satisfied, 4 very satisfied and 5 completely satisfied. The values between 1 and 2.99 AR are in the range of dissatisfaction and 3 to 5 of satisfaction, presenting different intensities according to the values found.

\subsection{Sample Characterization}

The respondents of this research totaled 65 students graduating from the Federal University Campus in Ji-Paraná, $33,8 \%$ of the Physics course, $27,7 \%$ of the Pedagogy course, $20 \%$ of the Environmental Engineering course, $9.2 \%$ of the Mathematics course and $9,2 \%$ of the Statistics course.

The sample is predominantly female, represented by $66.2 \%$ of respondents, and $38.2 \%$ male, where there is a slight predominance of women as graduates at the university under study.

Regarding age, it was observed that the youngest student is 19 years old, the oldest 45 years old and the average age of all respondents is 27 years old, which represents a great diversity of ages. It was also observed that the highest concentration of respondents is less than 35 years old, that was 58 in total, and that the most recurrent age was 24 years old. Such information demonstrates that at the Ji-Paraná Campus, more young people are graduating than older people.

\subsection{Satisfaction With the Institution}

To measure the students' perception of satisfaction with the institution, the data collection instrument applied had a section with twelve attributes. Through the frequencies of each attribute, their AR was obtained and then their average was calculated to obtain the AR of each dimension.

Table 3. Elaborated by the authors

\begin{tabular}{ll}
\hline Satisfaction with the Institution & $\mathbf{A R}$ \\
\hline Attribute & 3,94 \\
\hline 1. Audiovisual resources and equipment available at the institution & 3,62 \\
\hline $\begin{array}{l}\text { 2. Service and clarity of information offered by employees of the secretariat and Course } \\
\text { Department }\end{array}$ & 3,03 \\
\hline 3. Equipment and software offered by the laboratories & 3,48 \\
\hline 4. Service and clarity of information offered by library staff & 3,08 \\
\hline 5. Collection available in the library (digital included) & 3,85 \\
\hline 6. Security offered by the institution (concierge, security guards) & 3,11 \\
\hline 7. Physical infrastructure of classrooms & 3,09 \\
\hline 8. Institution's physical infrastructure & 4,31 \\
\hline 9. Cleaning the institution & 3,31 \\
\hline 10. Services offered by the library & 3,28 \\
\hline 11. Comfort of the institution's facilities & 3,58 \\
\hline 12. Location of the different sectors that make up the institution & $\mathbf{3 , 4 7}$ \\
\hline AR (average) & \\
\hline
\end{tabular}


The average of the AR's of the attributes of the dimension "Satisfaction with the Institution" was calculated, which resulted in 3.47. Through this value it can be inferred that the students are satisfied with the Institution, and the attribute that represented the greatest satisfaction was the "cleanliness of the institution" where the students are very satisfied against the worst result which was the attribute "equipment and software offered laboratories", where the students are satisfied, but the result found is very close to dissatisfaction.

Comparing the results found in this research with the authors who developed similar researches, with the same methodology, it was found that Salomão, Abacar and Aliante (2018) also obtained, in the dimension "Satisfaction with the Institution", students satisfied with $43.4 \%$ of responses and well or totally satisfied with $24.5 \%$. With this result, it appears that, as in the Pedagogical University - Nampula Delegation, the students of the Federal University of Rondônia Campus de Ji-Paraná are satisfied with their institution.

In general, based on the results found, the Campus of Ji-Paraná needs to improve its laboratories, its library (collection, services and attendance provided), its infrastructure and comfort to improve students' satisfaction with the Institution.

The satisfaction with the institution is important, because is by the perceived image by the students that other people will have the intention of studying in the same institution, and consequently improve the success of the organization in the society.

\subsection{Course Satisfaction}

The measurement of satisfaction with the course deserves special treatment, separated by course, in order to assess the satisfaction of the students, providing a detailed report for this dimension, since the results found may serve as a basis for institutional improvements. In this sense, this topic has been subdivided into two parts, general data and cross data.

\subsubsection{General Data}

The methodology used in the analysis was the same as the Satisfaction with the Institution dimension, where the AR's of each attribute (Table below) were calculated based on the frequencies found. To obtain the AR of the dimension, the average of the AR's found in each attribute was calculated.

Table 4. Elaborated by the authors

\begin{tabular}{ll}
\hline Course Satisfaction & AR \\
\hline Attribute & 3,91 \\
\hline 13. Relationship with teachers & 4,05 \\
\hline 14. Relationship with classmates & 3,85 \\
\hline 15. Adequacy between personal involvement in the course and the academic performance obtained & 4,02 \\
\hline 16. Teachers' interest in attending students during classes & 4,11 \\
\hline 17. Teachers' knowledge of the content of the subjects they teach & 3,77 \\
\hline 18. Recognition by teachers of my involvement with my education & 3,80 \\
\hline 19. Institution's commitment to formation quality & 3,80 \\
\hline 20. Evaluation proposed by teachers & 3,75 \\
\hline 21. Class strategy used by teachers & 3,86 \\
\hline 22. Relevance of course content & 3,77 \\
\hline 23. Teachers willingness to serve students outside the classroom & 3,82 \\
\hline 24. Adequacy of course content for student formation & 3,69 \\
\hline 25. Adequacy between the tasks required in the course and the time established by the teachers to \\
perform
\end{tabular}


The average of the AR's of the attributes of the dimension "Satisfaction with the Course" resulted in 3.86, which represents the satisfaction of the students in relation to the courses they attend. The attributes that had the highest index were "Knowledge of teachers about the content of the subjects they teach", "Relationship with colleagues in the course" and "Interest of teachers in attending students during classes" respectively. Through this, it is inferred that teachers have a good command of the contents and seek to serve students well during classes, and that students have a good relationship with each other.

In contrast to the present study, where students are satisfied with their courses, Salomão, Abacar and Aliante (2018) obtained the greatest dissatisfaction from the students, with $30.1 \%$ not very satisfied and $20.3 \%$ not at all satisfied. Thus, the methodology applied in this dimension showed different results between the University of Nampula and the Federal University of Rondônia, in Ji-Paraná.

\subsubsection{Course Satisfaction Data Separated by Course}

It is important to measure satisfaction with the course with the sample stratified by the course they are linked to. Such observation may serve for coordination and teachers to improve and identify weaknesses and strengths. The scale used ranged from 1 to 5 , so the points below are all in the range of student satisfaction.

Table 5. Elaborated by the authors

\section{Course satisfaction stratified by course}

\begin{tabular}{|c|c|c|c|c|c|}
\hline \multirow[b]{2}{*}{ Attribute } & \multicolumn{5}{|l|}{ AR per course } \\
\hline & $\begin{array}{l}\text { Environmental } \\
\text { Engineering }\end{array}$ & Statistic & Physics & Mathematics & Pedagogy \\
\hline 13. Relationship with teachers & 3,85 & 4,33 & 3,95 & 4,33 & 3,61 \\
\hline 14. Relationship with classmates & 3,69 & 4,67 & 4,18 & 3,83 & 4,00 \\
\hline $\begin{array}{l}\text { 15. Adequacy between personal involvement } \\
\text { in the course and the academic performance } \\
\text { obtained }\end{array}$ & 3,62 & 4,17 & 3,77 & 3,83 & 4,00 \\
\hline $\begin{array}{l}\text { 16. Teachers' interest in attending students } \\
\text { during classes }\end{array}$ & 3,92 & 4,33 & 4,09 & 4,17 & 3,83 \\
\hline $\begin{array}{l}\text { 17. Teachers' knowledge of the content of the } \\
\text { subjects they teach }\end{array}$ & 3,92 & 4,50 & 4,18 & 4,33 & 3,94 \\
\hline $\begin{array}{l}\text { 18. Recognition by teachers of my } \\
\text { involvement with my education }\end{array}$ & 3,62 & 4,33 & 3,59 & 4,17 & 3,78 \\
\hline $\begin{array}{l}\text { 19. Institution's commitment to education } \\
\text { quality }\end{array}$ & 3,62 & 4,17 & 3,77 & 4,00 & 3,78 \\
\hline 20. Evaluation proposed by teachers & 3,38 & 4,17 & 3,86 & 3,83 & 3,89 \\
\hline 21. Class strategy used by teachers & 3,46 & 4,33 & 3,86 & 3,50 & 3,72 \\
\hline 22. Relevance of course content & 3,77 & 4,50 & 3,73 & 3,67 & 3,94 \\
\hline $\begin{array}{l}\text { 23. Teachers willingness to serve students } \\
\text { outside the classroom }\end{array}$ & 3,92 & 4,00 & 3,95 & 3,83 & 3,33 \\
\hline $\begin{array}{l}\text { 24. Adequacy of course content for the student } \\
\text { formation }\end{array}$ & 3,62 & 4,17 & 3,77 & 4,00 & 3,83 \\
\hline $\begin{array}{l}\text { 25. Adequacy between the tasks required in } \\
\text { the course and the time established by the } \\
\text { teachers to perform }\end{array}$ & 3,69 & 3,83 & 3,64 & 3,83 & 3,67 \\
\hline Average AR & 3,70 & 4,27 & 3,87 & 3,95 & 3,79 \\
\hline
\end{tabular}


Through the observed values, it is concluded that, in general, all students are satisfied with their courses, highlighting the Statistics course, which presented 4.27 points, where it fits with high satisfaction, followed by the Mathematics course with 3.95 points, which falls within satisfaction, but very close to values considered high satisfaction.

Consequently, it is also in the statistics course that the highest AR scores appear, which were 4.50 in the attributes "Knowledge of teachers" and "Relevance of the content of the subjects" showing high quality in the teaching given to these students.

It is observed that some aspects had lower scores, which deserves to be highlighted by the Institution in order to improve, such as "Availability of teachers to attend students outside the classroom", which received 3.33 points and "Adequacy between tasks required in the course and the time established by the teachers for completion "which received 3.67 points in the Pedagogy course," Evaluation proposed by the teachers "which received 3.38 points in the Environmental Engineering course.

\subsection{Satisfaction With the Development Opportunity}

Like the other dimensions, the Development Opportunity had ten attributes and by calculating the AR and its average, the result is presented in the Table below.

Table 6. Elaborated by the authors

\begin{tabular}{ll}
\hline Satisfaction with the Development Opportunity & $\mathbf{A R}$ \\
\hline Attribute & 3,40 \\
\hline 26. Diversity of extracurricular activities offered by the institution & 3,89 \\
\hline 27. Course Curriculum & 3,23 \\
\hline 28. Social events offered by the institution & 3,65 \\
\hline 29. Personal involvement in the course activities & 3,34 \\
\hline 30. Student support programs or services offered by the institution & 3,63 \\
\hline 31. Conditions offered for my professional development (knowledge and skills for acting) & 3,34 \\
\hline 32. Conditions for entering the professional education area (insertion strategies and contact with & 3,14 \\
\hline the world of work) & 3,38 \\
\hline 33. Financial support program offered by the institution & 3,54 \\
\hline 34. Personal development opportunity offered by the institution & $\mathbf{3 , 4 5}$ \\
\hline 35. Adequacy between my financial investment to pay for studies and training received \\
\hline Average AR
\end{tabular}

The average of the AR's of the attributes of this dimension was 3.45, which is within the area of student satisfaction. It is observed that the least satisfaction in this dimension was in relation to "Financial support programs offered by the institution", where they even had comments on the subject, saying that the transport aid should not be so difficult to get, especially for students who do not live in Ji -Paraná. Parallel to this, with an assessment of 3.34 points, also below the general average, is the attribute "Programs or services to support students offered by the institution".

There is also a lack of "social events offered by the institution" since this attribute was in the penultimate place in the ranking with 3.23 points and "strategies for insertion and contact with the world of work" which was 3.34 points. Reflection of these aspects are found in the comments of the students, where a certain student mentions that one of the problems of the Environmental Engineering course is not allowing the student to have contact with the job market and another student of statistics says that the Institution does not support the holding of events, it is sometimes the responsibility of teachers to defray expenses, such as the Course Exhibition that was held recently.

Despite the satisfaction presented, the mentioned aspects can be improved, as a strategy to cause interest in possible new entrants, as well as guarantee the permanence, for example, of those who have doubts if at the end of the course they will get a job related to their education. 
Similar to the present study, it was the result found by Salomão, Abacar and Aliante (2018) in this dimension, where $64.4 \%$ of the respondents fell within the satisfaction interval, with the majority declaring themselves "satisfied" with $33.6 \%$.

\subsection{Implications, Limitations and Future Research}

Although this research presents reliable results and achieves its objective, it has the limitation of having been carried out only with students from undergraduate courses, and, therefore, it is considered interesting that new studies are carried out, aiming to analyze student satisfaction as a whole., encompassing all students. In addition, the research data source occurred solely through the application of questionnaires, so, in new studies, interviews could be conducted with a sample of respondents, to better understand their wishes regarding the institution, the course and the opportunity for development.

This survey can also be applied to all the campuses of the Federal University of Rondônia, thus revealing the degree of satisfaction with the institution in general. Finally, also as an opportunity for research related to the theme, it would be prudent to analyze the existence of a relationship between the (in) satisfaction of students with academic dropout, at the campus in Ji-Paraná and other institutions.

It is very important for the society that the educational institutions prepare the students for the real life, giving them the tools to manage real situations, which sometimes go beyond the general knowledge given by the courses. It is imperative that the object of study meet the needs of society, and also the needs of the students, in the sense of filling the blanks in terms of professionals' availability for the market, at the same time that it is important to meet the students expectations regarded to their professional life. In that way, this study can contribute by giving some feedback to the educational institution studied, to be able to understand part of these needs by the perception of their own students.

\section{Final Considerations}

The present research had as objective to know the degree of satisfaction of the students of the Federal University of Rondônia, Campus of Ji-Paraná. The attributes that were selected for the survey were due to the relevance presented, since the SSAE matrix was widely used for research of this type in different places, moments and audiences. Through this, there was also the delimitation of the dimensions evaluated.

Through the results, it was possible to understand that the graduating students of the Federal University in the city of Ji-Paraná are satisfied with the Institution, with the course in which they are linked and in the course of formation, and also with the opportunity for development, supporting, then, the hypothesis proposed in the methodology section.

This study is only a first step towards understanding the Federal University of Rondônia's academic satisfaction. As can be seen in the theory presented, checking the perception of academic satisfaction is very useful for managers to better manage the educational institution.

Given the present work and its results, the managers of the Federal University, Campus of Ji-Paraná, will be able to access a brief diagnosis about the quality of the services provided to students and thus create and promote strategies to increase the levels of satisfaction of their target audience that it is society in general, promoting a more satisfactory social profit. Such results may contribute to increase the demand for students at FHEI as well as increase the permanence rate.

\section{References}

Barboza, S. I. S., Carvalho, D. L. T. De., Soares Neto, J. B., \& Costa, F. J. Da. (2014). Uma análise dos condicionantes da satisfação, da dedicação e do desempenho de estudantes de cursos de administração. Administração: ensino e pesquisa, 15(2), 323-349. https://doi.org/10.13058/raep.2014.v15n2.23

Creswell, J. W. (2010). Projeto de pesquisa: métodos qualitativo, quantitativo e misto (3rd ed.). Porto Alegre: Artmed Editora.

Dias, C. L., Horiguela, M. De L., \& Marchelli, P. S. (2006). Políticas para avaliação da qualidade do Ensino Superior no Brasil: um balanço crítico. Educação e Pesquisa, 32(3), 435-464. https://doi.org/10.1590/S1517-97022006000300002

Durham, E. R. (2009). A qualidade do ensino superior. Revista @mbienteeducação, 2(1), 09-14. https://doi.org/10.26843/ae19828632v12n32019p170a193 
Fadel, C. B., Souza, J. A. De., Bordin, D., Garbin, C. A. S., Garbin, A. J. I., \& Saliba, N. A. (2018). Satisfaction with the academic experience among graduate students of abrazilian public university. RGO, Revista Gaúcha de Odontologia, 66(1), 50-59. https://doi.org/10.1590/1981-863720180001000073261

Floriano, M. D. P., Silva, A. H., \& Dorneles, F. M. (2017). Marketing educacional : formulação de estratégias de marketing para a Universidade Federal do Pampa, campus Santana do Livramento. Anais do II Fórum Internacional Conecta PPGA. Santa Maria, RS, Brasil. Retrieved from https//www.even3.com.br/anais/forumconecta/67647-MARKETING-EDUCACIONAL--FORMULACAO-DEESTRATEGIAS-DE-MARKETING-PARA-A-UNIVERSIDADE-FEDERAL-DO-PAMPA-CAMPUS-SANT ANA

Fonseca, C. V., \& Santos, F. M. T. (2015). O curso de Licenciatura em Química da UFRGS: Estudo da Estrutura Curricular e de aspectos constitutivos da formação docente. Alexandria: Revista de Educação em Ciência e Tecnologia, 8(3), 81-111. https://doi.org/10.5007/1982-5153.2015v8n3p81

Kotler, P., \& Fox, K. F. A. (1994). Marketing estratégico para instituições educacionais. São Paulo: Atlas.

Kotler, P., \& Keller, K. L. (2012). Administração de Marketing (14th ed.). São Paulo: Pearson Education do Brasil.

Mainardes, E. W., \& Domingues, M. J. (2010). Satisfação de estudantes formandos em administração de Joinville/SC com o seu curso e com sua instituição de ensino superior: aspectos relacionados ao mercado de trabalho. Revista Eletrônica de Ciências Administrativas, 9(1), 49-61. https://doi.org/10.5329/RECADM.20100901004

Malhotra, N. K. (2012). Pesquisa de Marketing: Uma orientação aplicada (6th ed.). Porto Alegre: Bookman.

Moreira, D. A. (2003). Didática do ensino superior: técnicas e tendências.São Paulo: Pioneira.

Ramos, A. M., Barlem, J. G. T., Lunardi, V. L., Barlem, E. L. D., Silveira, R. S. Da., \& Bordignon, S. S. (2015). Satisfação com a experiência acadêmica entre estudantes de graduação em enfermagem. Texto e Contexto Enfermagem, 24(1), 187-195. https://doi.org/10.1590/0104-07072015002870013

Salomão, I. F. C. De S., Abacar, M., \& Aliante, G. (2018). Satisfação acadêmica em estudantes do curso de graduação em Ensino Básico da Universidade Pedagógica - Delegação de Nampula. Revista Brasileira de Ensino Superior, 4(1), 24-42. https://doi.org/10.18256/2447-3944.2018.v4i1.2239

Santos, A. A. A. Dos., Polydoro, S. A. J., Scortegagna, S. A., \& Linden, M. S. S. (2013). Integração ao Ensino Superior e Satisfação Acadêmica em Universitários. Psicologia: Ciência e Profissão, 33(4), 780-793. https://doi.org/10.1590/S1414-98932013000400002

Santos, M. A. C., \& Romeiro, V. (2017). A satisfação com a experiência acadêmica influencia a relação de confiança comportamental com a instituição?. Revista Brasileira de Ensino Superior, 3(1), 78-97. https://doi.org/10.18256/2447-3944/rebes.v7n1p78-97

Schleich, A., Polydoro, S., \& Santos, A. (2006). Escala de satisfação com a experiência acadêmica de estudantes do ensino superior. Avaliaçao Psicologica: Interamerican Journal of Psychological Assessment, 5(1), 11-20. Retrieved

from https://www.researchgate.net/publication/235743763_Escala_de_satisfacao_com_a_experiencia_academica_de _estudantes_do_ensino_superior

Silva, E. M. Da., Silva, E. M. Da., Gonçalves, V., \& Murolo, A. C. (1997). Estatística para os cursos de Economia, Administração e Ciências Contábeis (Vol. 2, 2th ed.). São Paulo: Atlas.

Vaduva, S. A., Fotea, I. S., Corcea, M., \& Lazar, M. (2011). Beyond satisfaction: engaging students and faculty in a Romanian business school. Marketing Management Journal, 21(1), 207-213. Retrieved from http://www.mmaglobal.org/publications/MMJ/MMJ-Issues/2011-Spring/MMJ-2011-Spring-Vol21-Issue1-Com plete.pdf 


\section{Appendix}

Comments Left by Students in the Questionnaire

1. Physics

"My only question is about aid, because I think that for those who live in another city, transportation aid is of paramount importance, it shouldn't be something that had to be so disputed, at least not this one! Because I see many people who do not need are receiving, while others who really need do not receive."

"I would like teachers to update themselves more, as there are teachers who don't even know 9th grade math to teach in the course!"

2. Environmental engineering

"One of the deficient points with the course is in relation to not allowing the student's contact with the job market."

"A very stressful course, which makes most people give up, a full time course that should only be at night, five years is a long time."

\section{Statistics}

"The lack of interest from the faculty in making improvements to the courses. An example is showing that the course was totally disorganized and without support from the college itself, where teachers take out of their pockets to do any type of event because the college says it has no "resources". This is growth both for academics and for society and MAINLY FOR COLLEGE, because every event bears the name of UNIR (Federal University of Rondônia)."

\section{Pedagogy}

"It is satisfactory because we learn everything we need for our life outside of university." 